\title{
PUMA mediates the anti-cancer effect of osimertinib in colon cancer cells [Corrigendum]
}

Guo L, Huang S, Wang X. PUMA mediates the anti-cancer effect of osimertinib in colon cancer cells. Onco Targets Ther. 2017;10:5281-5288.

The authors have advised that the affiliations are not correct, the affiliation list should be:
${ }^{1}$ Department of Pathology, The First Affiliated Hospital of Soochow University, Soochow, Jiangsu, ${ }^{2}$ Department of Oncology, Nanjing Medical University Affiliated Cancer Hospital, Nanjing, Jiangsu, China

OncoTargets and Therapy

\section{Publish your work in this journal}

OncoTargets and Therapy is an international, peer-reviewed, open access journal focusing on the pathological basis of all cancers, potential targets for therapy and treatment protocols employed to improve the management of cancer patients. The journal also focuses on the impact of management programs and new therapeutic agents and protocols on

patient perspectives such as quality of life, adherence and satisfaction. The manuscript management system is completely online and includes a very quick and fair peer-review system, which is all easy to use. Visit http://www.dovepress.com/testimonials.php to read real quotes from published authors. 